$\begin{array}{r}\text { Interdisciplinary Contexts of Special Pedagogy } \\ \text { NUMBER 31/2020 } \\ \text { MACIEJ MUSKAŁA } \\ \text { University of Adam Mickiewicz Poznań, Poland } \\ \hline\end{array}$

\title{
Relapses in the process of desistence from offending
}

\begin{abstract}
Maciej Muskała, Relapses in the process of desistence from offending. Interdisciplinary Contexts of Special Pedagogy, no. 31, Poznań 2020. Pp. 319-338. Adam Mickiewicz University Press. ISSN 2300-391X. e-ISSN 2658-283X. DOI: https://doi. org/10.14746/ikps.2020.31.15

Many offenders follow the "zigzag path", interlacing many times criminal and noncriminal stages. The aim of this survey review is to show, on the example of the SelfRegulatory Model of Relapse Prevention analyses (SRM-r in modified version) the variety of ways and courses of action that an offender (mainly sexual) may follow in the process of desistance from offending.
\end{abstract}

KEY WORDS: relapses, Self-Regulation Model of Relapse Prevention, zigzag path

\section{Foreword}

Whereas some criminal careers are short-lived or even incidental and free of recidivism ${ }^{1}$, other careers are persistent and with

${ }^{1}$ It is worth noting the valuable observation made by T.E. Moffitt, who identified two groups of offenders: those who manifest antisocial behaviour throughout their entire lives (life-course persistent offenders) and those who commit offences only in adolescence (short-term adolescent offenders), incidentally or only once, see: T.E. Moffitt, Adolescence-Limited and Life-Course-Persistent Antisocial Behavior: A Developmental Taxonomy, "Psychological Review" 1993, vol. 100(4), pp. 674-701; A.R. Piquero, T.E. Moffitt, Explaining the Facts of Crime: How the Developmental Taxon- 
numerous relapses to the path of crime. Thus, from a theoretical perspective - rather than thinking in simplistic, rigid offender/nonoffender categories - D. Matza offered the image of "drift/tendency" to capture the instability of offending over time. ${ }^{2} \mathrm{D}$. Glaser suggests that it is more appropriate to see criminality as a "zigzag path" consisting of crime and non-crime cycles. In his studies on former offenders, he proved that they "followed the zigzag path from noncrime to crime and to non-crime again. Sometimes, the sequence is repeated many times (...); sometimes these shifts are for a long duration or even permanent and sometimes they are short-lived". 3 Thus, the offender rehabilitation process, the change that takes place in the offender's life, the change that takes place in the offender, the withdrawal from criminal activity should be seen as a long and dynamic process. Along this process, there are numerous relapses to the "old" criminal behaviour that are more or less within the control of the individual concerned. Those relapses are triggered not by individual causes but rather by many different coexisting factors. G.A. Marlatt and J.R. Gordon ${ }^{4}$ divided relapse-related situations into two categories. "The first is the category of intrapersonal/environment factors that mainly include personal, internal factors and/or reactions to external events in the environment (...) The other category consists of interpersonal factors related to interpersonal events". 5

omy Replies to Farrington's Invitation, [in:] D.P. Farrington (ed.), Integrated Developmental and Life-Course Theories of Offending, New Brunswick 2005, pp. 51-72.

2 D. Matza, Delinquency and Drift, New York 1964, after: J.H. Laub, R.J. Sampson, Shared Beginnings, Divergent Lives: Delinquent Boys to Age 70, Cambridge-Massachusetts-London 2003, p. 36.

${ }^{3}$ D. Glaser, The Effectiveness of a Prison and Parole System, Indianapolis 1969, p. 58, after: J.H. Laub, R.J. Sampson, Understanding Desistance from Crime, "Crime and Justice" 2001, vol. 28, p. 54.

${ }^{4}$ G.A Marlatt, J.R. Gordon, Determinants of relapse: Implications for the maintenance of behavior change, [in:] P.O. Davidson, S.M. Davidson (eds.), Behavioral medicine: Changing health lifestyles, Elmsford 1980, pp. 410-452

${ }^{5}$ G.J. Connors, C.C. DiClemente, M.M. Velasquez, D.M. Donovan, Etapy zmiany w terapii uzależnień, Wybór i planowanie interwencji, Kraków 2015, pp. 282-283 
The purpose of this review is to show, on the basis of the SelfRegulation Model of Relapse Prevention (in the modified version SRM-R), the diversity of paths and means that an offender (specifically sexual offender) may follow in the process of desistence from offending.

\section{Relapses - theoretical review}

Most studies on relapses were associated with disorders caused by psychoactive substance abuse and dependence. Thus, some of the theories or theoretical models that explain the phenomenon of relapse focus on factors, desires and needs that induce the use of those substances. ${ }^{6}$ This paper, offering a much more broader approach to the issue, covering all the problematic behaviours (also behaviours that are against the law), presents only the concepts that have or might have such broad, universal nature. They include models that focus on cognitive functions and are generally referred to as psychological models.

The model of self-efficacy and the expected outcome - which draws on A. Bandura's self-efficacy concept. The model considers two issues: the expected potential effects of one's own behaviour (the prediction that specific behaviour leads to a specific result) and own efficacy (the belief that one is able to accomplish such behaviour). "In this theory, self-efficacy is the resultant of an individual's repertoire of coping strategies and social skills. The more negative expectations an individual accumulates as a result of different experiences

${ }^{6}$ The psychobiological models of relapse include: Ludwig and Wikler's model of hunger and loss of control, Solomon's model of opponent processes, Tiffany's model of craving and hunger, Mossberg et al's withdrawal syndrome model or post-acute withdrawal syndrome model. For more information on this issue, see: M. Wojnar, A. Ślufarska, A. Jakubczyk, Nawroty w uzależnieniu od alkoholu, część 1; Definicje i modele, Alkoholizm i Narkomania 2006, vol. 19, no. 4, pp. 386-390; G.J. Connors, C.C. DiClemente, M.M. Velasquez, D.M. Donovan, Etapy zmiany w terapii uzależnień, Wybór i planowanie interwencji, Kraków 2015, pp. 278-280 and the literature cited therein. 
(...) and the lower their sense of control over those experiences and their own behaviour, the more likely the individual is to relapse".7

The cognitive assessment model - focuses on the subjective assessment of a situation. Reaction is defined as threatening not because of the fact that a certain situation occurred but because of a subjective feeling of being threatened by that situation. To some extent, this concept has the same theoretical bases as the former model, since it assumes that an individual's assessment of the significance of a given situation is to a large extent determined by whether or not the individual feels they have effective coping strategies.

The cognitive-behavioural model - in which relapse is triggered by an unsuccessful attempt to cope with a situation, defined by G.A. Marlatt and J.R. Gordon, the founders of the concept, as "highrisk situation". These situations constitute the interpersonal-environment factor of relapse. They include: pressure from others or interpersonal conflicts but also escalation of positive situation or experiences. The other triggering factor is internal, intra-personal and it mainly involves negative emotional states and giving in to temptations and whims. If an individual reacts successfully to an increased-risk situation, "their sense of self-efficacy grows stronger and it will protect them from future relapses in similar situations. If, however, an individual fails to resist (...), their self-esteem, sense of self-efficacy and coping skills diminish". 8

The person-situation interaction model - which is only a modification of the cognitive-behavioural concept. "Relapse is determined by mutual interaction of the following three elements: situations that an individual sees as dangerous (i.e. high-risk situations), coping strategy resources adequate to a given situation and whether or not an individual considers those strategies to be relevant and effective". 9

${ }^{7}$ M. Wojnar, A. Ślufarska, A. Jakubczyk, Nawroty w uzależnieniu od alkoholu, część 1 ..., p. 385.

${ }^{8}$ M. Wojnar, A. Ślufarska, A. Jakubczyk, Nawroty w uzależnieniu od alkoholu, część $1 \ldots$, p. 384.

${ }_{9}^{9}$ G.J. Connors, C.C. DiClemente, M.M. Velasquez, D.M. Donovan, Etapy zmiany w terapii uzależnień, Wybór i planowanie interwencji, Kraków 2015, p. 279. 


\section{The Self-Regulation Model of Relapse Prevention - SRM)}

As has already been noted, even though most theoretical assumptions were based on and empirically verified in the context of behaviours related to psychoactive substance abuse and dependency, the concepts of relapse are also relevant to other problematic and criminal behaviours.

In mid 1980, a team led by W.D. Pithers started creating a model that would explain sexual offence relapse. ${ }^{10}$ The main assumption was to identify the affective, cognitive and behavioural factors of relapse in order to ensure relapse prevention intervention. If offence is seen to be beyond the offender's control and if the abovementioned factors are not identified, effective intervention will be very unlikely. ${ }^{11}$

Although the model proposed by W.D. Pithers et al was an important step in the development of relapse prevention with sexual aggressors, it was widely criticised for its limited perspective and oversimplification of the prevention process. The proposed single path did not explain all the possible patterns of criminal behaviour. These and other limitations in W.D. Pithers' relapse prevention model were addressed in a number of crucial models developed at the turn of the century. One of the most important of those models was the multipath Self-Regulation Model of Relapse Prevention - SRM) developed by T. Ward and S.M. Hudson. ${ }^{12}$

"The model is founded on the theory of self-regulation, which is seen as a set of internal and external processes that allow and en-

10 Cf.: W.D. Pithers, J.K. Marques, C.C. Gibat, G.A. Marlatt, Relapse prevention with sexual aggressives: A self-control model of treatment and maintenance change, [in:] J.G. Greer, I.R. Stuart (eds.), The sexual aggressor: Current perspectives on treatment, New York 1983, pp. 214-239.

11 More on this issue: J.A. Keeling, J.L. Rose, Relapse Prevention with Intellectually Disabled Sexual Offenders, "Sexual Abuse: A Journal of Research and Treatment" 2005, vol. 17(4), p. 409.

12 T. Ward, S.M. Hudson, A self-regulation model of relapse prevention, [in:] D.R. Laws, S.M. Hudson, T. Ward (eds.), Remaking relapse prevention with sex offenders, Thousand Oaks 2000, pp. 79-101. 
courage an individual to participate in goal-directed behaviour. The goals are described as cognitive scripts that are stored as behavioural scenarios, enabling an individual to interpret their own actions or the actions of others and are ultimately linked with positive and negative emotions. The goals of self-regulation are the states that an individual wants either to avoid or to achieve. Self-regulation is concerned with more than inhibiting unwanted behaviour, and can also include the enhancement and maintenance of positive emotional states and behaviour" ${ }^{13}$

Self-regulation problems may increase the probability of relapse in sexual offenders. Three styles of problematic self-regulation have been identified. The first is when an individual does not control their thoughts, feelings and behaviour, which leads them to a sexual offence. Secondly, an individual may try to control their behaviour, but the strategies he or she uses are inefficient or insufficient, so the individual cannot effectively manage their behaviour. Finally, an offender may be capable of efficient self-regulation but in a dysfunctional way, because he or she self-regulates themselves in order to achieve goals that are associated with improper sexual behaviour.

Initially, the model consisted of nine phases, but its current revised version SRM-R covers ten phases that are fluid and represent different stages in which an offender may intervene and end the relapse process by applying relevant coping strategies.

The Self-Regulation Model of Relapse Prevention (modified as SRM-R) is an integrated model and it was developed on the basis of the theoretical assumptions and conceptual apparatus of the broader theory of offender rehabilitation approaches developed by T. Ward and called the Good Lives Model - GLM. The Good Lives Model (GLM) represents the latest theoretical framework of offender rehabilitation approaches. Unlike the models that focus on risk management, GLM draws on positive psychology and focuses on developing the strengths and potential of socially maladjusted individuals. Without disregarding the achievements of the "what works" move-

${ }^{13}$ J.A. Keeling, J.L. Rose, Relapse Prevention ..., p. 410. 
ment, GLM empowers an offender by promoting their needs and goals in life. ${ }^{14}$

Because the founders of the SRM-R model make frequent references to the GLM conceptual apparatus, it is necessary to briefly describe the most important assumptions of the GLM concept. ${ }^{15}$

Based on psychological, social, biological and anthropological studies, GLM assumes that as human beings, offenders have the same preferences and basic needs as other people and are naturally predisposed to seek out certain goals or primary human goods that constitute the fundamental values and life goals of an individual. T. Ward and his colleagues proposed the following eleven primary goods: (a) life (including healthy living and functioning, ensuring one's safety), (b) knowledge (learning and getting to know oneself and other people or gaining knowledge about other issues that one considers to be important and interesting), (c) excellence in play, (d) excellence in work, (e) excellence in agency ${ }^{16}$ - i.e. autonomy and self-directedness (fulfilling the need for independence and subjectivity), (f) inner peace (i.e. freedom from emotional turmoil and stress), (g) friendship (including intimate, romantic, and family relationships), (h) community (belonging to a social group or community that shares the same values and interests), (i) spirituality (in the broad sense of finding meaning and purpose in life), (j) happiness and $(\mathrm{k})$ creativity (understood the need to try something new, to

14 For more information on the dispute between representatives of the two theoretical schools see: M. Muskała, Odstąpienie od przestępczości..., p. 182 and ff.

${ }^{15}$ For more information on this issue in Polish literature, see e.g.: K. Biel, Model ryzyka i model dobrego życia w readaptacji skazanych, [in:] J. Kusztal, K. Kmiecik-Jusięga red. Konteksty resocjalizacji i readaptacji społecznej, Kraków 2014; E. Wysocka, Diagnoza pozytywne w resocjalizacji. Model teoretyczny i metodologiczny, Katowice 2015, M. Muskała, Odstapienie od przestępczości w teorii i praktyce resocjalizacyjnej, Poznań 2016.

16 The term 'agency' has multiple interpretations (and translations). In Polish literature, as K. Iwińska observes in her insightful analysis of the concept, 'agency' is the most frequently translated as: subjectivity, subjective agency or agency that is understood as intentional activity of an individual or free will of a subject, see K. Iwińska, Być i działać w społeczeństwie, Kraków 2015, pp. 25-59. 
take on new challenges). ${ }^{17}$ It should be noted, however, that "The problem with the concept of 'primary goods' in the Good Lives Model is that the 'good' does mean the 'goal'. 'Primary goods' are the state that we seek". ${ }^{18}$

Even though it is assumed that all individuals to some extent seek all those primary goods, the significance of and preference for respective goods reflect the particular values and priorities an individual has in life as well as the kind of person he or she is and the purposes they have. This is so-called vertical coherence, i.e. a hierarchical arrangement of goods characteristic of every individual. Horizontal coherence - the other relationship between goods described by $\mathrm{T}$. Ward at al - means the reciprocity of goods: the fact that certain goods exist enables other goods to come into being. ${ }^{19}$ Specific means and ways to achieve primary goods are, according to the founders of GLM, instrumental or secondary goods. In order to understand the relationship between the two types of goods, it is suggested to assume that secondary goods consist of specific roles, practices and actions that ensure attainment of primary goods. For example: life - pursuing a healthy diet, engaging in regular exercise, earning money to meet basic existential needs; knowledge - attending school, self-study, receiving advice from others; being good at play - participating in a sport arts and crafts; being good at work being employed or volunteering, advancing in one's career; personal choice and independence - following through with life plans,

17 See, for example, T. Ward, T.A. Gannon, Rehabilitation, Etiology, and SelfRegulation..., p. 79; T. Ward, S. Maruna, Rehabilitation..., p. 113; T. Ward, P.M. Yates, G.M. Willis, The Good Lives Model and the Risk Need Responsivity Model: A Critical Response to Andrews, Bonta, and Wormith (2011), "Criminal Justice and Behavior" 2012, vol. 39(1), p. 95.

18 D.S. Prescott, Terapia osób, których zachowania seksualne krzywdzą innych. Motywacja, ustalanie celów, model dobrego życia, [in:] J.M. Jaraczewska, M. Adamczyk-Zientara (ed.), Dialog Motywujacy. Praca z osobami uzależnionymi behawioralnie, Warszawa 2015, p. 185.

${ }^{19}$ M. Parvis, T. Ward, G. Willis, The Good Lives Model in Practice: Offence Pathways and Case Management, "European Journal of Probation” 2011, vol 3(2), p. 7. 
expressing one's own opinion; peace of mind - any activities that help manage emotions, such as exercise or meditation, but also substances; friendships - Spending time with friends, having an intimate relationship with another person, also a relationship that may be hurtful for oneself or for others; community - belonging to a social organization or sports team, also being a member of a gang; spirituality - going to church or engaging in other religious activities; happiness - "most often, people attain this good when socialising with friends, watching movies, having sex, engaging in thrill-seeking activities, drinking alcohol, taking drugs"20; creativity - various types of artistic expression, participating in new or novel activities.

The SRM-R describes the progression of criminality. It provides for the aetiology of criminal behaviour, beginning with the life event that triggers the desire to commit an offence and ending with two post-offence phases when individuals evaluate their behaviour and formulate their expectations and attitude as regards their future criminality.

The model includes four separate pathways $s$ delineating the progression to offending based on a combination of offence-related goals that may be based either on avoidance strategy or on approach strategy, or on a combination of the two (Phase five of the model).

The offenders whose goal is to avoid want to refrain from offending but they lack the necessary skills to achieve that goal. Their selfregulation is poor (the avoidant-passive path). When they have an opportunity to commit an offence, they utilize passive strategies, such as distraction of attention, to achieve that goal. The other group of offenders whose goal is to avoid also desire to avoid offending and they actively implement strategies that help achieve that goal (the avoidant-active pathway). This is a pathway of misregulated self-regulation. To avoid offending, an offender employs ineffective strategies that in fact increase the risk of offending. The other two pathways focus on the approach. These are: the approach-

${ }^{20}$ D.S. Prescott, Terapia osób..., p. 189. 
automatic pathway, where individuals do not want to avoid offending and react automatically to situational cues by activating deeply rooted scenarios; and the approach-explicit pathway, where self-regulation is intact and individuals actively employ strategies to commit an offence. ${ }^{21}$

The ten phases of the modified Self-Regulation Model of Relapse Prevention (SRM-R) are briefly described below. ${ }^{22}$

\section{Phase 1: Preconditions to sexual offending}

This is a new phase that was not included in the original SRM. It was added in order to acknowledge background and predisposing factors. The reason was the fact that for some individuals, the occurrence of a life event (see below) triggers a progression to sexual offending, whereas for other individuals, the same event will not trigger such a progression. ${ }^{23}$ The difference between these individuals lies in differences in their developmental histories, and psychological, social, biological, and other factors. Thus, background factors will influence the manner in which individuals respond throughout the offence progression and, therefore, provide valuable information for understanding the different pathways to offending followed by individual offenders. This points to the importance of a comprehensive understanding of predisposing factors to offending, which was absent in the original SRM.

21 P.M. Yates, T. Ward, Good Lives, Self-Regulation, and Risk Management: An Integrated Model of Sexual Offender Assessment and Treatment, "Sexual Abuse in Australia and New Zealand" 2008, vol. 1(1), p. 7.

22 The description of the respective phases of SRM-R is based on: T. Ward, S.M. Hudson, A self-regulation model... oraz P.M. Yates, T. Ward, Good Lives, SelfRegulation, and Risk Management: An Integrated Model of Sexual Offender Assessment and Treatment, "Sexual Abuse in Australia and New Zealand" 2008, vol. 1(1), pp. 3-20.

23 This observation is a clear reference to the findings of the supporters of the narrative perspective in the process of desistance from offending, according to which it is not an event or a cumulation of events but rather their interpretation that matters, which suggests that internal factors are important. For more information on this issue, see: M. Muskała, Odstapienie od przestępczości w teorii i praktyce resocjalizacyjnej, Poznań 2016, p. 159 and ff and the authors cited therein. 
Phase 2: Life event

This stage begins when a specific life event occurs. It may be a relatively common event, such as a minor argument with a partner or co-worker, or a major life transition, such as loss of a relationship or the death of someone close to the individual. The individual appraises and evaluates the event relatively automatically, based on experience, cognitive schema, implicit theories, goals and interpersonal context in which the event occurs. Goals may be specific to a particular situation or there may be more abstract goals that are linked to the individual's self-concept and views of the world. In this phase, individuals interpret and appraise the event based on cognitive schema and underlying causal theories about the world and themselves that assist the individual to explain and make predictions about the world and events. The function of this process is to guide and direct behaviour, cognition, and affect in response to the life event. In the original SRM, the occurrence of the life event was presumed to trigger a desire for offensive behaviour, specifically among individuals attempting to remain "abstinent". In the reconstructed model, consistent with the GLM, the life event may trigger the desire to achieve primary goods and important goals that are not necessarily related to offending, and which may suggest flaws or problems in the individual's good lives plan. Thus, the occurrence of the life event that triggers the offence progression is viewed from a much broader perspective and does not focus solely on direct routes to offending or that can trigger goals other than specifically offence-related goals. Thus, in the SRM-R, the triggering life event may provoke various states: (1) the desire to obtain or to re-establish a particular primary good or other positive goal; (2) the desire to re-establish equilibrium; (3) the identification of flaws in the good lives plan and the desire to address these flaws; and/or (4) the desire to offend.

Phase 3: Desire in response to life event

The occurrence of the life event can trigger desires that result in offending as well as desires that are not deviant in nature Moreover, the desire triggered by the life event may be, in fact, an appropriate 
desire, as in those cases in which the individual seeks to obtain primary goods or other states in response to the life event. That is, the life event may trigger the desire to regain such states as autonomy, relatedness, or intimacy, thus re-establishing equilibrium in the individual's good lives plan In these cases, the desire for offensive or deviant sexual behaviour emerges later in the offence progression.

\section{Ph a se 4: Goal establishment}

In this phase, the goals are explicitly linked to desires triggered during the previous phase, with respect to offensive behaviour arising both from the desire to offend and to achieve the desired end. Thus, at this stage in the offence progression, goals may be established either to obtain primary goods or other desired states, or they may be offence-specific. ${ }^{24}$

The concepts of approach and avoidance goals are also expanded in this phase. The original SRM conceptualised these goals as the desire to refrain from offending (avoidance goals) or to seek out offending (approach goals). In the SRM-R, these offence-related goals remain; however, individuals at this stage may also establish prosocial or non-offending approach goals. For example, individuals holding avoidance goals with respect to offending, may also simultaneously hold approach goals with respect to other states or goods sought. That is, individuals who desire to avoid acting on offencerelated desires may, at the same time, also desire to seek out a particular state of being that is non-offensive in nature. As in the original SRM, avoidance goals with respect to offending are generally

${ }^{24}$ For example, for an individual for whom the life event triggered the desire to re-acquire the primary good of relatedness, the goal established at this stage will be directly in service of acquiring this good (e.g., re-establishing a relationship a secondary good), even though this ultimately results in behaviour that leads to the commission of a sexual offence. For some individuals, such as those following an indirect route to offending, the establishment of offence-specific goals occurs later in the offence progression. Conversely, for those individuals for whom the life event triggered an offensive or deviant desire, the goals established at this stage will be offence-related and the route to offending may be more likely a direct route. 
associated with negative emotional states, whereas approach goals with respect to both offending and non-offending behaviour may be associated with either positive or negative emotional states depending upon the individual and what they seek to achieve.

Phas e 5: Strategy selection

In this phase, the individual selects strategies to achieve the goal established in the previous phase of the offence progression. In the SRM-R, the selection of strategies follows the same processes as in the original model, and, in combination with offence-related goals, forms the four self-regulation pathways to offending (avoidantpassive, avoidant-active, approach-automatic, and approach-explicit). These pathways are specific to the offence process, although they may also reflect individuals' overall self-regulation styles. People typically tend to have similar self-regulation styles across various life areas, particularly offenders following the approach pathways. Moreover, the founders of the SRM-R suggest that individuals following avoidant pathways are more pro-social in other life areas than offenders following approach pathways, which is supported by research indicating that these individuals tend to have fewer prior convictions, demonstrate less general criminality and, consequently, be lower risk. ${ }^{25}$

This reconstruction of this phase therefore acknowledges that individuals may seek to obtain multiple goods via offending, either separately or concurrently, and may do so directly or indirectly. Furthermore, individuals may seek to achieve a desired state while simultaneously selecting strategies to avoid offending (an undesired state) and to attain a primary good (a desired state). It is proposed that offenders with less extensive criminal histories are able to man-

25 Cf. P.M. Yates, D.A. Kingston, Pathways to sexual offending: Relationship to static and dynamic risk among treated sexual offenders, "Sexual Abuse: A Journal of Research and Treatment" 2006, vol. 18(3), pp. 259-270; J.A. Bickley, A.R. Beech, Implications for treatment of sexual offenders of the Ward and Hudson model of relapse, "Sexual Abuse: A Journal of Research and Treatment" 2003, vol. 15(2), pp. 121-134. 
age these life areas relatively well as a result of greater opportunities to obtain goods in non-offending ways. Finally, if the individual has not yet established an offence-related goal but rather has established a non-offending goal, the strategies selected at this phase will be in service of this goal, with the specific offence-related goal established later in the offence progression.

Ph a s e 6: Opportunity to Achieve Goals

The SRM-R conceptualises this phase of the offence progression as one in which the opportunity to achieve goals is presented as a result of the goals and strategies established during Phases 4 and 5 . This phase refers to the opportunity for the individual to achieve approach or avoidance goals, both with respect to offending and in relation to acquiring primary goods or other desired (nonoffending) states. In terms of the affective states associated with this phase, for individuals holding offence-avoidance goals, the opportunity to offend signifies a failure to achieve goals and to control or inhibit behaviour, is predominantly associated with negative affective states, and may result in goal conflict. For individuals holding approach goals with respect to offending, the opportunity signals success and is predominantly associated with positive affective states. For individuals holding non-offending goals at this stage, the opportunity presented is to achieve non-offending goals or primary goods, and is likely to be associated with positive affective states. If the individual simultaneously holds offence and pro-social goals, affect is likely to be mixed.

Ph a se 7: Pre-offence behaviours

This phase is somewhat refined in the SRM-R compared to the original model. First, as in the original model, the occurrence of the opportunity to achieve goals (Phase 6) signals a failure to avoid offending among individuals following an avoidant pathway and success in achieving goals for individuals following an approach 
pathway. In addition, as indicated above, the SRM-R also allows for plans and strategies that are established in order to obtain primary goods. As such, the founders of the model propose that the opportunity to achieve goals (Phase 6) signals to the individual that these primary goods are available, and may therefore signal success, regardless of self-regulation pathway. That is, actions at this phase may continue to represent attempts to achieve the primary good or pro-social approach goal that became available during the previous phase. Actions at this phase of the offence progression may not represent offence-related behaviours per se, although they ultimately function to place the individual at risk to offend nonetheless. In the SRM-R, this state is therefore viewed as existing either independently of pre-offence behaviours or as co-existing alongside pre-offence behaviours. Thus, the individual may simultaneously abandon offence-avoidance goals as well as engage in behaviour to acquire the primary good; may abandon efforts to obtain the primary good and engage solely in offending behaviour; or may attempt to obtain the primary good via offending. Individuals who have not yet established an offence-related goal do so at this phase as a result of a lack of capacity or resources to obtain non-offending goals or goods via non-offending means.

Ph a s e 8 - Commission of offence

This phase includes the interrelationships between offencerelated goals and non-offending life goals. That is, the individual is hypothesised to commit the offence as a result of failure to achieve offence-avoidance goals (avoidant pathways) or success in achieving offence-related goals (approach pathways), as well as success or failure in obtaining primary goods and pro-social goals. As indicated above, the commission of an offence may represent the means by which primary and other goods and pro-social goals are obtained among individuals who lack the capacity to acquire these via nonoffending means and who are predisposed by various factors to obtain these goods and goals via offending. 
Ph a s e 9 - Post-offence evaluation

Adjustment of Good Lives Plan

In the SRM-R, this phase is refined compared to SRM to better reflect its temporal nature as the period of time immediately following the commission of the offence and the reinforcement for behaviour that occurs at this phase. P.M. Yates and T. Ward claim that in addition to affective responses and evaluations that are negative or positive based on the offence pathway the individual has followed, reinforcement for behaviour occurs as a function of gratification obtained, either via positive reinforcement (e.g., sexual gratification, achievement of intimacy) or negative reinforcement (e.g., removal of negative affect). This reinforcement necessarily serves to entrench offending behaviour as a means by which goals are achieved, regardless of pathway. In the SRM-R, this phase of the offence progression also includes evaluation of behaviour with respect to achieving the good lives plan in addition to an evaluation of offending behaviour. Thus, individuals who have successfully obtained a primary good, regardless of a success or failure experience with respect to offending, also experience reinforcement for offending as a means to obtain good lives and other non-offending goals.

Ph a se 10 - Future intentions and adjustments to good lives plan

In this phase, individuals utilise the offence experience to develop, refine, and formulate future intentions and expectations with respect to offending, and to entrench or alter attitudes regarding the acceptability of offending. It is assumed that individuals with avoidance goals reassert control and may resolve not to offend in future, but lack the requisite internal and external conditions and capacities to achieve this goal, whereas individuals with approach goals learn from the offence experience to refine strategies to achieve these goals. Through the processes of reinforcement described above in Phase 9, for all individuals, such behavioural scripts are reinforced by the offending process and will impact on future behaviour.

The difference between pathways lies in the evaluation of behaviour as positive or negative (success versus failure) in achieving 
the initial offence-related goals. Individuals following avoidant pathways will experience cognitive dissonance between their behaviour and goals, and, if the avoidant goal is retained at this phase, are likely to propose attributions which thus permit the individual to resolve to change behaviour and to refrain from offending in the future. Individuals following approach pathways will not experience cognitive dissonance (as there is no discrepancy between goals and behaviour), and will attribute behaviour in a manner which absolves them of responsibility (e.g. via blaming the victim). In addition, in the SRM-R it is proposed that individuals formulate future plans, intentions and expectations not only with respect to offending, but also with respect to achieving the good lives plan. As with offending, individuals may conclude that they lack the requisite capacities and opportunities to implement the plan and may adjust the plan so as to abandon specific elements or goals. Alternatively, individuals may conclude that they successfully achieved the element of the plan sought (i.e., the good lives goal) and, thus, in conjunction with reinforcement for behaviour, formulate intentions that include the offence experience as a means by which to obtain that particular primary good. In this case, the individual may make adjustments to the good lives plan and to behaviour that include the offence experience as a means by which to obtain primary goods and to achieve the plan.

\section{Conclusion}

The founders of the above multi-pathway Self-Regulation Model of Relapse Prevention - SRM, T. Ward and S.M. Hudson, use multiple intellectual inspirations. They themselves stress that the broadest theoretical framework is positive psychology and focus on building strengths and emphasising potentials. Accordingly, their deliberations, associated with offender rehabilitation models, reflect the T. Ward's Good Lives Model. Other inspirations may also be found in the SRM model, for example L. Festinger's theory of cognitive 
dissonance ${ }^{26}$ (in fact, the entire avoidant pathway is founded on the idea of cognitive dissonance). Another major inspiration is the trans-theoretical model of change proposed by J.O. Prochaska and C.C. DiClemento ${ }^{27}$, according to which relapses are a normal thing, since many individuals go through respective phases more than once before achieving a stable change.

The model presented in this paper gives completely new answers to basic questions about offending, desistance and relapse. What is relapse in the case of individuals whose problematic behaviour involves violation of the law? In the "old" understanding, without going into specific legal discussion, it may be called simply as recidivism. And that is something that triggers strong negative emotion. Recidivism is very problematic for offender rehabilitation practitioners and theoreticians as well as for the "designers" of criminal policies and it arouses fear in people. Recidivism should be stopped at all costs. But is such thinking justified? Perhaps the phenomenon of offensive relapse should not and does not have to trigger such emotions? Not only because, as T. Szymanowski notes, the problem of recidivism, considering the type or gravity of offences, is not so much dangerous as it is troublesome because of its repeatability, high costs and "marginalisation and exclusion of individuals with a criminal history from social life"28. But also because it is "in a sense a natural phenomenon in a society, the same as criminality in general" 29 , and this fact should be reflected in offender rehabilitation models as well as in criminal policies. Beginning with a diagnosis of relapse in an individual case and of the stage the individual is at a given moment, through the process of interactions, focusing more on preventing than reacting to relapses. Thus, the Self-Regu-

${ }^{26}$ L. Festinger, Teoria dysonansu poznawczego, Warszawa 2007.

27 J.O. Prochaska, J.C. Norcross, C.C. DiClemente, Zmiana na dobre, rewolucyjny program zmiany w sześciu stadiach, który pozwoli ci przezwyciężyć złe nawyki i nada twojemu życiu właściwy kierunek, Warszawa 2008.

28 T. Szymanowski, Recydywa w Polsce. Zagadnienia prawa karnego, kryminologii i polityki karnej, Warszawa 2010, p. 18.

${ }^{29}$ T. Szymanowski, Recydywa w Polsce..., p. 17. 
lation Model of Relapse Prevention should also be applied in criminal policies and the resulting legal regulations and should be taken into consideration while defining the functions and tasks of the personnel of the offender rehabilitation system, in the broad meaning of the term.

\section{References}

Biel K., Model ryzyka i model dobrego życia w readaptacji skazanych, [in:] J. Kusztal, K. Kmiecik-Jusięga (red.), Konteksty resocjalizacji i readaptacji społecznej, Kraków 2014.

Bickley J.A., Beech A.R., Implications for treatment of sexual offenders of the Ward and Hudson model of relapse, "Sexual Abuse: A Journal of Research and Treatment" 2003, vol. 15(2).

Connors G.J., DiClemente C.C., Velasquez M.M., Donovan D.M., Etapy zmiany w terapii uzależnień, Wybór i planowanie interwencji, Kraków 2015.

Festinger L., Teoria dysonansu poznawczego, Warszawa 2007.

Keeling J.A., Rose J.L., Relapse Prevention with Intellectually Disabled Sexual Offenders, "Sexual Abuse: A Journal of Research and Treatment" 2005, vol. 17(4).

Laub J.H., Sampson R.J., Shared Beginnings, Divergent Lives: Delinquent Boys to Age 70, Cambridge-Massachusetts-London 2003.

Moffitt T.E., Adolescence-Limited and Life-Course-Persistent Antisocial Behavior: A Developmental Taxonomy, "Psychological Review" 1993, vol. 100(4),

Muskała M., Odstapienie od przestępczości w teorii i praktyce resocjalizacyjnej, Poznań 2016.

Piquero A.R., Moffitt T.E., Explaining the Facts of Crime: How the Developmental Taxonomy Replies to Farrington's Invitation, [in:] D.P. Farrington (ed.), Integrated Developmental and Life-Course Theories of Offending, New Brunswick 2005.

Pithers W.D., Marques J.K., Gibat C.C., Marlatt G.A., Relapse prevention with sexual aggressives: A self-control model of treatment and maintenance, [in:] J.G. Greer, I.R. Stuart (eds), The sexual aggressor: Current perspectives on treatment, New York 1983.

Prochaska J.O., Norcross J.C., DiClemente C.C., Zmiana na dobre, rewolucyjny program zmiany w sześciu stadiach, który pozwoli ci przezwyciężyć złe nawyki i nada twojemu życiu właściwy kierunek, Warszawa 2008.

Szymanowski T., Recydywa w Polsce. Zagadnienia prawa karnego, kryminologii i polityki karnej, Warszawa 2010.

Ward T., Hudson S.M., A self-regulation model of relapse prevention, [in:] D.R. Laws, S.M. Hudson, T. Ward (eds.), Remaking relapse prevention with sex offenders, Thousand Oaks 2000. 
Wojnar M., Ślufarska A., Jakubczyk A., Nawroty w uzależnieniu od alkoholu, część 1; Definicje i modele, "Alkoholizm i Narkomania" 2006, tom 19, nr 4.

Wysocka E., Diagnoza pozytywne w resocjalizacji. Model teoretyczny i metodologiczny, Katowice 2015.

Yates P.M., Ward T., Good Lives, Self-Regulation, and Risk Management: An Integrated Model of Sexual Offender Assessment and Treatment, "Sexual Abuse in Australia and New Zealand" 2008, vol. 1(1).

Yates P.M., Ward T., Good Lives, Self-Regulation, and Risk Management: An Integrated Model of Sexual Offender Assessment and Treatment, "Sexual Abuse in Australia and New Zealand" 2008, vol. 1(1).

Yates P.M., Kingston D.A., Pathways to sexual offending: Relationship to static and dynamic risk among treated sexual offenders, "Sexual Abuse: A Journal of Research and Treatment" 2006, vol. 18(3). 